\title{
PENERAPAN PENDEKATAN SAINTIFIK UNTUK MELATIHKAN \\ LITERASI SAINTIFIK DALAM DOMAIN KOMPETENSI \\ PADA TOPIK GERAK LURUS DI SEKOLAH MENENGAH PERTAMA
}

\section{SKRIPSI}

Diajukan untuk memenuhi sebagian syarat memperoleh gelar Sarjana Pendidikan

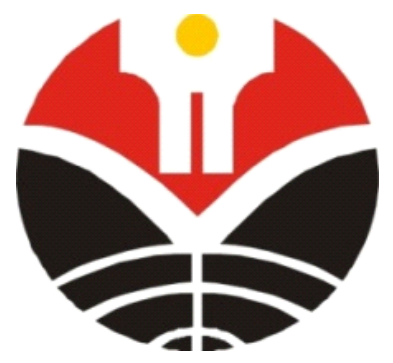

Oleh :

Adib Rifqi Setiawan

1204818

DEPARTEMEN PENDIDIKAN FISIKA

FAKULTAS PENDIDIKAN MATEMATIKA DAN ILMU PENGETAHUAN ALAM UNIVERSITAS PENDIDIKAN INDONESIA 


\section{PENERAPAN PENDEKATAN SAINTIFIK UNTUK MELATIHKAN \\ LITERASI SAINTIFIK DALAM DOMAIN KOMPETENSI \\ PADA TOPIK GERAK LURUS DI SEKOLAH MENENGAH PERTAMA}

\section{LEMBAR HAK PENGGUNAAN}

Oleh :

Adib Rifqi Setiawan

Sebuah skripsi yang diajukan untuk memenuhi sebagian syarat memperoleh gelar Sarjana Pendidikan pada Program Studi Pendidikan Fisika Departemen Pendidikan Fisika

Fakultas Pendidikan Matematika dan Ilmu Pengetahuan Alam Universitas Pendidikan Indonesia

(C) Adib Rifqi Setiawan 2017

Universitas Pendidikan Indonesia

Februari 2017

Hak Penggunaan dilindungi oleh undang-undang.

Skripsi ini boleh diperbanyak sebagian atau seluruhnya dengan berbagai cara tanpa ijin tertulis dan lisan dari penulis selama dicantumkan sebagai referensi. 


\section{PERNYATAAN}

Saya menyatakan bahwa seluruh isi skripsi berjudul "Penerapan Pendekatan Saintifik untuk Melatihkan Literasi Saintifik dalam Domain Kompetensi pada Topik Gerak Lurus di Sekolah Menengah Pertama” ini adalah karya saya sendiri. Saya tidak melakukan penjiplakan maupun pengutipan menggunakan cara yang tidak sesuai dengan kaidah dan etika yang berlaku dalam masyarakat akademik. Atas pernyataan ini, saya siap menanggung risiko apabila di kemudian hari ditemukan adanya pelanggaran kaidah dan etika terhadap keotentikan karya ini.

Bandung, 23 Februari 2017

Yang membuat pernyataan,

$\underline{\text { Adib Rifqi Setiawan }}$

NIM. 1204818 


\title{
PENERAPAN PENDEKATAN SAINTIFIK UNTUK MELATIHKAN \\ LITERASI SAINTIFIK DALAM DOMAIN KOMPETENSI \\ PADA TOPIK GERAK LURUS DI SEKOLAH MENENGAH PERTAMA
}

\author{
Penulis : : Adib Rifqi Setiawan, 1204818 \\ Pembimbing I : Dr. Setiya Utari, M.Si. \\ Pembimbing II: Muhamad Gina Nugraha, M.Si., M.Pd. \\ Departemen Pendidikan Fisika FPMIPA \\ UPI 2017
}

\begin{abstract}
ABSTRAK
Literasi Saintifik (LS) adalah adalah penguasaan konsep dan proses sains serta bisa menerapkan penguasaan tersebut dalam menyelesaikan masalah dan pengambilan keputusan. Beberapa negara melatihkan LS untuk menyiapkan warga negaranya, namun hasil penilaian PISA dan beberapa penelitian menunjukkan bahwa LS siswa Indonesia rendah. Penelitian dengan menggunakan metode pre-experimental dengan desain onegroup pretest-posttest design pada sampel sebanyak 36 siswa yang dipilih menggunakan teknik convenience sample di salah satu sekolah di Kabupaten Bandung Barat ini menerapkan pendekatan saintifik untuk melatihkan LS. Pengujian dilakukan menggunakan tes uraian sebanyak 18 soal dengan reliabilitas tes sebesar 0,72. Hasil penelitian menunjukkan desain pembelajaran topik gerak lurus di sekolah menengah pertama dengan menggunakan pendekatan saintifik yang telah dirancang mendapat tanggapan siswa hampir maksimal pada setiap tahap kegiatan pembelajaran serta peningkatan domain kompetensi pada kategori sedang masing-masing: $\mathrm{K} 1\langle g\rangle=0,52$; $\mathrm{K} 2\langle g\rangle=0,60$; dan $\mathrm{K} 1\langle g\rangle=0,69$.

Kata-kata kunci : Literasi Saintifik; Domain Kompetensi; Pendekatan Saintifik; Gerak Lurus
\end{abstract}


IMPLEMENTED THE SCIENTIFIC APPROACH

TO TRAIN SCIENTIFIC LITERACY IN DOMAIN COMPETENCE AT JUNIOR HIGH SCHOOL IN TOPIC LINEAR MOTION

\author{
Author : Adib Rifqi Setiawan, 1204818 \\ Advisor : Dr. Setiya Utari, M.Si. \\ Co-Advisor : Muhamad Gina Nugraha, M.Si., M.Pd. \\ Physics Education Department Faculty of Educational Sciences \\ UPI 2017
}

\begin{abstract}
Scientific Literacy is a mastery of concepts and processes of science and can applying it to solve problems and make decision. Several states trains scientific literacy at the school to prepare their citizens, but the assessment by PISA and researches shows that scientific literacy of Indonesian students is low. Research using pre experimental with one group pretest-posttest design on a sample of 36 students which were selected using convenience sample technique at one school in Kabupaten Bandung Barat is implemented the scientific approach to train scientific literacy. Tests used by 18 essay questions with a reliability of the test is 0.72 . The research reports that learning design in topic linear motion at junior high school using a scientific approach that has been designed can be got almost maximum student responses at each stage of learning activitie as well as an improvement at moderate category in each domain competence: $C 1\langle g\rangle=0,52 ; C 2\langle g\rangle$ $=0,60$; and $C 3\langle g\rangle=0,69$.
\end{abstract}

Keywords : Scientific Literacy; Domain Competence; Scientific Approach; Linear Motion 


\section{Ucapan Terima kasih}

Penulisan skripsi bisa diselesaikan dengan banyak bantuan teknis dan dorongan psikis dari berbagai pihak. Dengan demikian, penulis mengucapkan terima kasih kepada seluruh pihak yang telah membantu, terutama:

1. Ibu Dr. Setiya Utari, M.Si., selaku Pembimbing Akademik, Pembimbing I, sekaligus rekan mengobrol personal yang telah membimbing penulis selama mengikuti perkuliahan serta khususnya pada penyelesaian skripsi;

2. Bapak Muhamad Gina Nugraha, M.Pd., M.Si., selaku Pembimbing II yang telah membimbing penulis selama penyelesaian skripsi;

3. Seluruh dosen Program Studi Pendidikan Fisika dan dosen lain yang telah memberikan pengajaran dan pendidikan pada penulis selama perkuliahan;

4. Bapak Drs. Tarma Anda, selaku guru IPA SMPN 02 Lembang yang telah memberikan kesempatan untuk melakukan penelitian;

5. Siswa SMPN 02 Lembang yang telah bersedia menjadi objek penelitian;

6. Rohis Umi Hanik dan Munadi, S.Pd.I. selaku orangtua yang selalu memberikan dorongan psikis pada penulis;

7. Naintina Ella Laily Tsani dan Hikmal Rifqi Afiful Lathif selaku adik yang selalu memberikan dorongan psikis pada penulis; serta

8. Eny Rochmwati Octaviani, Ahmad Ulul Albab, Muflih Muhammad Mahiry, Leily Hardianti Rosiana, dan Nur Hidayati selaku sahabat yang senantiasa menghibur ketika lara dan mengingatkan saat mapan. 


\section{DAFTAR ISI}

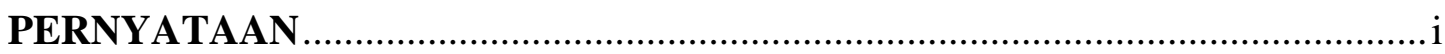

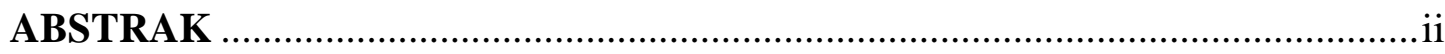

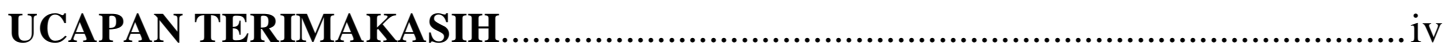

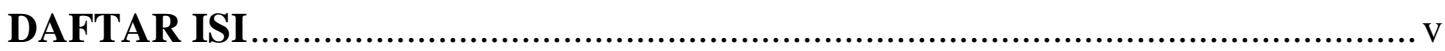

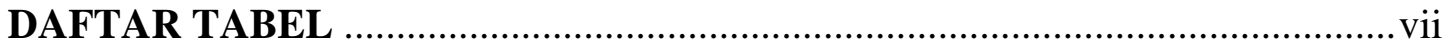

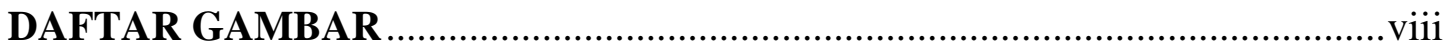

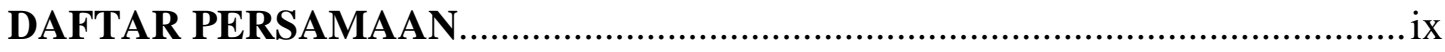

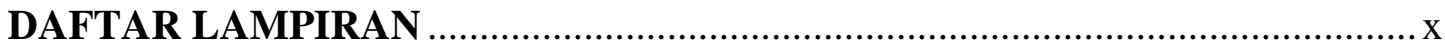

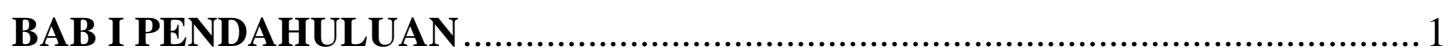

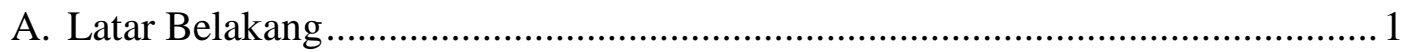

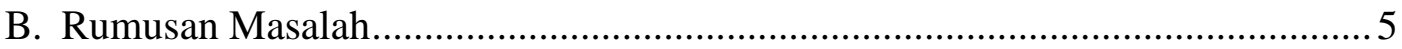

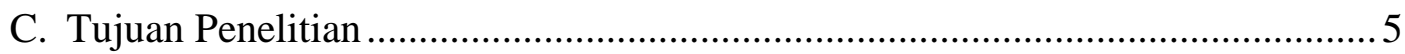

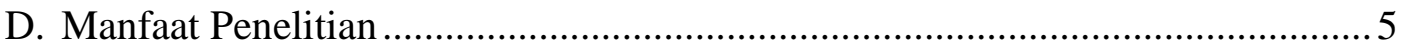

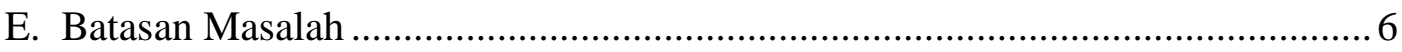

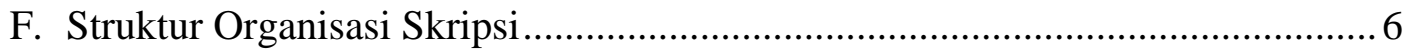

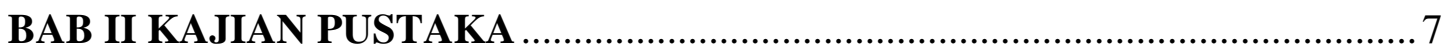

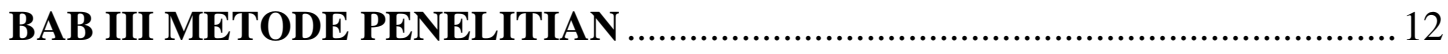
A. Desain Penelitian

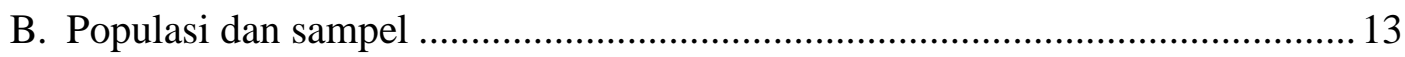

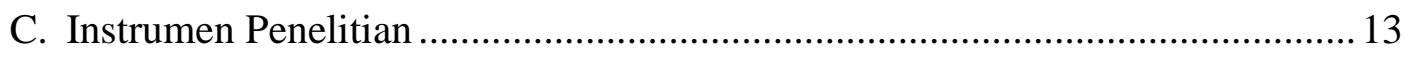
D. Prosedur Penelitian .................................................................................... 13 


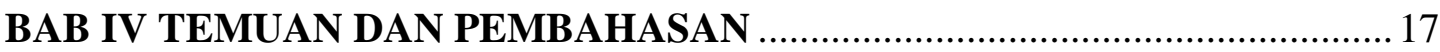
A. Temuan 17
B. Pembahasan 20

BAB V SIMPULAN, IMPLIKASI, DAN REKOMENDASI 22
A. Simpulan.
.22
B. Implikasi .22
B. Rekomendasi. 23

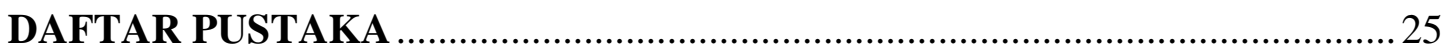

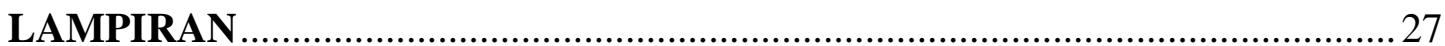




\section{DAFTAR TABEL}

Tabel 2.1. Hasil Penelitian Kurnia (2014) ............................................................. 8

Tabel 2.2. Tahapan Pembelajaran pada LOI ........................................................

Tabel 3.1. Penelitian One-Group Pretest-Posttest Design......................................... 12

Tabel 3.2. Kategori Peningkatan Nilai Gain ......................................................... 16

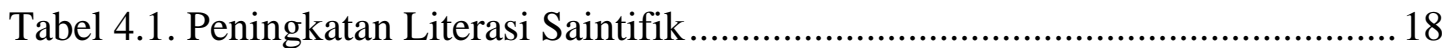




\section{DAFTAR GAMBAR}

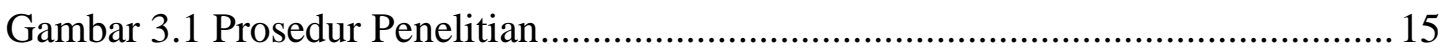

Gambar 4.1. Tanggapan Siswa Selama Pembelajaran .......................................... 17

Gambar 4.2. Peningkatan Setiap Domain Dalam Setiap Pertemuan ......................... 19 


\section{DAFTAR PERSAMAAN}

Persamaan 3.3.Penyekoran Pre-Test dan Post-Test ................................................. 16

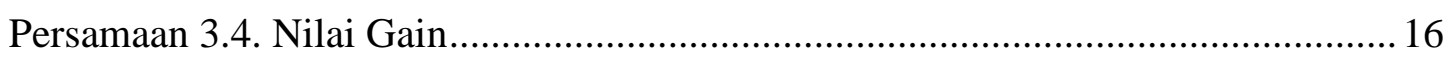




\section{DAFTAR LAMPIRAN}

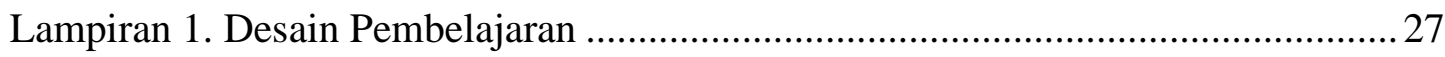

Lampiran 2. Lembar Kegiatan Siswa............................................................... 77

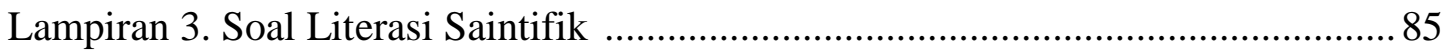

Lampiran 4. Temuan Literasi Saintifik Siswa (pretest) ........................................... 100

Lampiran 5. Temuan Literasi Saintifik Siswa (posttest)....................................... 102

Lampiran 6. Administrasi Penelitian ................................................................... 104 


\section{BAB I}

\section{PENDAHULUAN}

\section{A. Latar Belakang}

Istilah literasi saintifik pertama kali diberikan oleh Paul deHart Hurd yang menyebut bahwa literasi saintifik bermakna memahami sains dan penerapannya bagi kebutuhan masyarakat (Hurd, 1958, hlm. 1). Makna literasi saintifik juga diberikan oleh NAS (National Academy of Sciences) yang mendefinisikan literasi saintifik sebagai pengetahuan dan pemahaman tentang konsep-konsep sains dan proses yang diperlukan untuk pengambilan keputusan pribadi, berpartisipasi dalam keseharian warga negara dan budaya, serta ekonomi yang produktif (NAS, 1996, hlm. 22). PISA (The Programme for International Student Assessment) mendefinisikan literasi saintifik sebagai kemampuan untuk terlibat dengan permasalahan yang berkaitan dengan sains dan gagasan-gagasan sains sebagai cerminan warga negara (OECD, 2013, hlm. 7). Dari tiga definisi tersebut, dapat dimaknai bahwa literasi saintifik adalah penguasaan konsep dan proses sains serta bisa menerapkan penguasaan tersebut dalam menyelesaikan masalah dan pengambilan keputusan.

Literasi saintifik menjadi salah satu tujuan utama dalam pendidikan sains, selaras dengan penuturan Holbrook dan Rannikmae (2009, hlm. 286) bahwa literasi saintifik menjadi target pendidikan sains. Sebagai tujuan utama dalam pendidikan sains, literasi saintifik dalam keseharian masyarakat menjadi gambaran keberhasilan pendidikan sains yang dilakukan oleh setiap negara. Literasi saintifik merupakan modal dasar setiap individu dalam menghadapi tantangan global yang semakin kompleks terutama dalam memecahkan permasalahan yang ada dalam keseharian serta untuk meningkatkan daya saing internasional pada umumnya, sehingga penting dimiliki (Sudarisman, 2011, hlm. 253).

Beberapa negara seperti Singapura, Jepang, Estonia, Finlandia, dan Kanada terus berupaya untuk meningkatkan literasi saintifik masyarakatnya melalui pendidikan, dengan harapan supaya generasi muda 
dapat dipersiapkan dengan matang untuk mampu terlibat dalam persaingan global (OECD, 2016, hlm. 4). Upaya yang dilakukan membuat literasi saintifik menjadi acuan beberapa negara tersebut dalam menyusun kurikulum pembelajaran di sekolah. Di Indonesia sendiri, untuk mengarahkan pembelajaran selaras dengan literasi saintifik, Kementerian Pendidikan dan Kebudayaan Republik Indonesia (Kemdikbud RI) mengambil kebijakan dengan menerapkan tahapan pembelajaran $5 \mathrm{M}$, yaitu: mengamati, menanya, mengumpulkan informasi (melakukan percobaan), mengolah informasi (mengasosiasi), dan mengomunikasikan (Kementerian Pendidikan dan Kebudayaan, 2013). Melalui penerapan tahapan ini siswa dilatih supaya dapat menguasai dan menerapkan pengetahuan, memecahkan masalah, menemukan sesuatu untuk dirinya, dan berusaha keras untuk mewujudkan gagasannya.

Kemdikbud RI memang tidak menyebutkan literasi saintifik secara gamblang, namun kebijakan tersebut sudah selaras dengan domain yang terdapat dalam penilaian literasi saintifik oleh PISA. Domain yang terdapat dalam penilaian literasi saintifik mencakup empat domain yang saling terkait, yaitu: konteks, pengetahuan, kompetensi, dan sikap. Domain konteks berkaitan dengan isu-isu pilihan sebagai contoh permasalahan yang cocok dengan kurikulum pendidikan negara yang mencakup konteks personal, lokal/nasional, dan global. Domain pengetahuan adalah pemahaman tentang fakta, konsep, dan penjelasan teori mengenai pengetahuan ilmiah yang mencakup pengetahuan tentang alam dan teknologi (pengetahuan konten), cara memroduksi gagasan-gagasan sains (pengetahuan prosedural), dan cara yang digunakan untuk dapat membenarkan gagasan terkait sains (pengetahuan epistemik). Domain kompetensi mencakup kompetensi untuk menjelaskan fenomena sains, merancang dan mengevaluasi penyelidikan sains, serta menafsirkan data dan bukti sains. Sedangkan domain sikap adalah sikap terhadap pengetahuan yang ditandai dengan minat dalam sains dan teknologi, mengapresiasi pendekatan sains untuk penyelidikan, serta tanggapan dan kesadaran terhadap masalah lingkungan (OECD, 2013, hlm. 11-12). 
Indonesia telah beberapa kali ikut serta dalam penilaian literasi saintifik oleh PISA dengan hasil yang menunjukkan bahwa literasi saintifik siswa Indonesia terbilang rendah. Sebagian besar siswa Indonesia berada dalam level 1 literasi saintifik yang menunjukkan bahwa sebagian besar siswa Indonesia baru bisa mengidentifikasi fenomena biasa dari pengetahuan yang dimilikinya (Utari, dkk. 2015, hlm. 1). Penilaian tersebut juga menunjukkan sebagian kecil siswa Indonesia berada dalam level 2 literasi saintifik yang berarti sebagian kecil siswa Indonesia mampu mengidentifikasi fenomena dengan pengetahuan yang dimilikinya dalam konteks yang sering ditemui dan mampu membuat kesimpulan. Level 1 dan 2 terbilang rendah karena ada 6 level dalam penilaian PISA ini (OECD, 2013, hlm. 49).

Terdapat beberapa faktor yang mempengaruhi hasil penilaian PISA terhadap siswa Indonesia terkait literasi saintifik ini. Salah satunya adalah proses pembelajaran yang belum bisa memfasilitasi secara optimal untuk meningkatkan literasi saintifik siswa. Sebagai contoh, hasil observasi yang dilakukan dalam proses pembelajaran sains pada topik gerak lurus di salah satu SMP di Kota Bandung memperlihatkan bahwa proses pembelajaran sains di kelas belum memfasilitasi secara optimal untuk meningkatkan kemampuan sains siswa. Hal ini karena siswa belum dapat mengembangkan pertanyaan penyelidikan dan percobaan yang dibangun masih bersifat verifikasi (cookbook). Melalui wawancara, guru menyebutkan bahwa cara-cara untuk melatihkan literasi saintifik dipandang sulit baik dari segi waktu maupun perangkat pendukung percobaan (Alam, 2015, hlm. 2).

Kebiasaan proses pembelajaran seperti disebutkan bisa mengakibatkan literasi saintifik siswa menjadi rendah. Dengan demikian, diperlukan upaya perbaikan dalam proses pembelajaran supaya dapat meningkatkan literasi saintifik siswa. Upaya perbaikan yang dapat dilakukan bisa bermacam-macam, misalnya dengan menganalisis kandungan literasi saintifik dalam bahan ajar, mengembangkan tes literasi saintifik, serta menganalisis desain pembelajaran. 
Dalam penelitian ini, upaya perbaikan yang dipilih ialah dengan menganalisis desain pembelajaran yang diselaraskan terhadap domain literasi saintifik dan tuntutan kurikulum yang berlaku. Pilihan ini diambil karena dalam desain pembelajaran sudah menyertakan bahan ajar dan tes serta memberikan tindakan secara langsung pada siswa.

Penelitian mengenai desain pembelajaran berkaitan dengan literasi saintifik telah dilakukan, salah satunya oleh Alam (2015) yang melakukan analisis konten kurikulum yang ada dan Rencana Pelaksanaan Pembelajaran (RPP) yang disusun oleh guru bersangkutan. Penelitian tersebut menghasilkan profil kesulitan literasi saintifik siswa serta desain pembelajaran untuk melatihkan literasi saintifik siswa. Namun desain pembelajaran tersebut belum diterapkan untuk kegiatan pembelajaran sehingga belum bisa melihat hal yang perlu diperbaiki setelah penerapan dilakuan.

Penelitian yang menerapkan desain pembelajaran untuk melatihkan literasi saintifik siswa sudah dilakukan oleh Novili (2016) pada topik kalor. Dari penelitian tersebut diperoleh kesimpulan bahwa pembelajaran menggunakan desain pembelajaran dengan pendekatan saintifik pada topik kalor memberikan peningkatan literasi saintifik siswa pada domain kompetensi dalam kategori sedang serta ditemukan bahwa desain pembelajaran masih perlu diperbaiki pada setiap tahap.

Berdasarkan pemaparan tersebut, peneliti tertarik untuk melakukan penelitian untuk meningkatkan kemampuan literasi saintifik dengan menggunakan desain pembelajaran yang telah disusun oleh Alam (2015). Peneliti bermaksud untuk menerapkan desain tersebut untuk menganalisis tanggapan siswa selama kegiatan pembelajaran serta peningkatan literasi saintifik siswa. Dengan demikian, judul yang diambil dalam penelitian ini adalah "Penerapan Pendekatan Saintifik untuk Melatihkan Literasi Saintifik dalam Domain Kompetensi pada Topik Gerak Lurus di Sekolah Menengah Pertama". 


\section{B. Rumusan Masalah}

Berdasarkan pemaparan latar belakang masalah, rumusan masalah pada penelitian ini adalah, "Bagaimana penerapan pendekatan saintifik pada pembelajaran topik gerak lurus di SMP?"

Agar penelitian lebih terarah, maka rumusan masalah dikembangkan menjadi pertanyaan penelitian sebagai berikut:

1. Bagaimana tanggapan siswa selama penerapan pendekatan saintifik pada topik gerak lurus di SMP?

2. Bagaimana peningkatan literasi saintifik siswa dalam domain kompetensi setelah diterapkan pendekatan saintifik pada topik gerak lurus di SMP?

\section{Tujuan penelitian}

Sesuai dengan rumusan masalah yang telah disebutkan, maka tujuan umum penelitian ini ialah mendapat gambaran tanggapan siswa selama dan peningkatan kemampuan literasi saintifik siswa setelah diterapkan pendekatan saintifik pada topik gerak lurus di SMP yang bisa digunakan untuk memperbaiki desain pembelajaran yang telah dirancang.

Adapun tujuan khusus dari penelitian ini adalah :

1. Mendapatkan gambaran tanggapan siswa selama penerapan pendekatan saintifik pada topik gerak lurus di SMP.

2. Mendapatkan gambaran peningkatan literasi saintifik siswa dalam domain kompetensi setelah diterapkan pendekatan saintifik pada topik gerak lurus di SMP.

\section{Manfaat Penelitian}

Penelitian ini mememberi informasi tentang upaya meningkatkan literasi saintifik melalui pengembangan desain pembelajaran yang melatihkan literasi saintifik serta besar peningkatan yang dicapai dengan diterapkan kegiatan pembelajaran tersebut. Adapun manfaat penelitian ini adalah :

1. Sebagai bahan informasi mengenai desain pembelajaran yang dapat melatihkan literasi saintifik. 
2. Sebagai bahan alternatif solusi dalam mengembangkan cara untuk melatihkan literasi saintifik dengan menggunakan pendekatan saintifik pada desain pembelajaran sains.

\section{E. Batasan Masalah}

Agar masalah dalam penelitian ini tidak terlalu luas, maka diberi batasan sebagai berikut :

1. Literasi saintifik dalam penelitian ini mengacu pada kerangka kerja PISA 2015 yang dibatasi pada domain kompetensi.

2. Peningkatan literasi saintifik dilihat dari nilai rata-rata hasil pre-test dan post-test yang diukur dengan menggunakan nilai gain yang dinormalisasi $\langle g\rangle$.

\section{F. Struktur Organisasi Skripsi}

1. BAB I PENDAHULUAN : memaparkan latar belakang pengambilan masalah yang dijadikan fokus utama dalam penelitian, rumusan masalah penelitian, tujuan dilakukan penelitian, manfaat penelitian yang dilakukan, serta struktur organisasi skripsi.

2. BAB II KAJIAN PUSTAKA : memaparan kajian pustaka untuk menggambarkan posisi penelitian yang dilakukan terhadap hasil penelitian lain.

3. BAB III METODE PENELITIAN : memaparkan desain penelitian, partisipan, populasi, sampel, dan instrumen yang digunakan, serta prosedur penelitian yang menjelaskan tahapan yang dilakukan dalam mengumpulkan data penelitian yang dibutuhkan dan langkah analisis data penelitian.

4. BAB IV TEMUAN DAN PEMBAHASAN : memaparkan hasil penelitian yang dilakukan, disertai dengan pembahasan yang ditujukan untuk menjawab rumusan masalah dan pertanyaan penelitian yang disusun.

5. BAB V SIMPULAN DAN SARAN : memaparkan kesimpulan penelitian yang dilakukan disertai dengan saran untuk pembaca maupun peneliti selanjutnya yang berminat. 


\section{BAB II}

\section{KAJIAN PUSTAKA}

Penelitian tentang literasi saintifik telah dilakukan oleh banyak peneliti dari beberapa negara termasuk Indonesia. Setiap peneliti mengkaji bagian-bagian tertentu dalam literasi saintifik, misalnya menganalisis kandungan literasi saintifik (Kurnia, 2014) dalam bahan ajar dan kaitan literasi saintifik dengan kegiatan pembelajaran di sekolah (Arif, 2015).

Udompong dan Wongwanich (2014) melakukan penelitian terkait literasi saintifik dengan mengembangkan tes diagnostik literasi saintifik untuk sekolah dasar. Penelitian yang dilakukan berangkat dari anggapan Udompong dan Wongwanich (2014) bahwa literasi saintifik merupakan aspek yang sangat penting, sehingga perlu untuk mempersiapkan masyarakat yang memiliki literasi saintifik tinggi sejak dini. Oleh karena itu, populasi dalam penelitian ini ialah siswa kelas 6 sekolah dasar dengan pemilihan sample menggunakan random sampling. Tes diagnostik literasi saintifik yang dikembangkan oleh Udompong dan Wongwanich (2014) didasarkan pada kerangka kerja PISA 2009 dengan bentuk tes pilihan ganda yang terdiri dari 15 soal, masing-masing 5 soal untuk setiap aspek (pengetahuan, konteks, dan sikap). Luaran penelitian ini berupa koefisien Cornbarch Alpha untuk masing-masing aspek pengetahuan, konteks, dan sikap secara berurutan sebesar 0.506, 0.614, dan 0.325, yang menunjukkan bahwa tes ini sudah bisa digunakan.

Kurnia (2014) melakukan penelitian terkait literasi saintifik dengan tujuan untuk menganalisa kandungan tema literasi saintifik pada bahan ajar yang digunakan di sekolah menengah atas (SMA) serta mendapatkan cakupan kedalaman dan keluasan materi ajar untuk satuan pendidikan tingkat SMA. Penelitian tersebut menggunakan metode deskriptif yang dilakukan di dua sekolah dalam satu kecamatan. Pengolahan data dilakukan dengan cara menjumlahkan indikator literasi saintifik pada setiap kategori untuk setiap buku ajar, kemudian menghitung persentase kemunculan indikator literasi saintifik dari setiap buku. Hasil penelitian 
tersebut dapat digunakan sebagai dasar untuk penelitian tentang tingkat literasi sains pada siswa-siswa sekolah menengah atas serta acuan dalam menyusun bahan ajar.

Tabel 2.1. Hasil Penelitian Kurnia (2014)

\begin{tabular}{|c|c|c|c|c|c|c|c|c|}
\hline \multirow[b]{3}{*}{ No. } & \multirow[b]{3}{*}{$\begin{array}{l}\text { Kategori } \\
\text { Literasi } \\
\text { Saintifik }\end{array}$} & \multicolumn{6}{|c|}{ Buku } & \multirow[b]{3}{*}{ 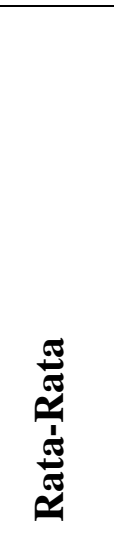 } \\
\hline & & \multicolumn{2}{|c|}{ SMA A } & \multicolumn{3}{|c|}{ SMA B } & \multirow[b]{2}{*}{ 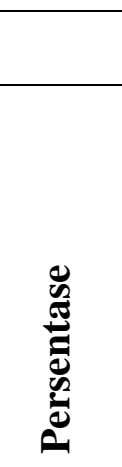 } & \\
\hline & & 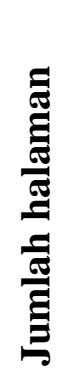 & 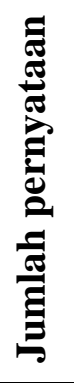 & 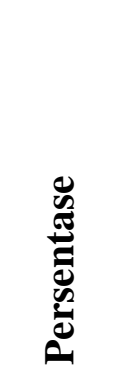 & 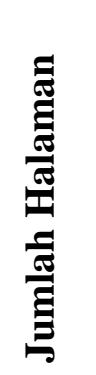 & 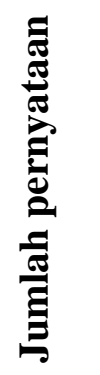 & & \\
\hline 1 & $\begin{array}{l}\text { Pengetahuan } \\
\text { sains }\end{array}$ & 60 & 231 & 85.24 & 310 & 547 & 34.00 & 59.62 \\
\hline 2 & $\begin{array}{l}\text { Sains sebagai } \\
\text { cara untuk } \\
\text { menyelidiki }\end{array}$ & & 36 & 13.30 & & 867 & 53.88 & 33.60 \\
\hline 3 & $\begin{array}{l}\text { Sains sebagai } \\
\text { cara berpikir }\end{array}$ & & 2 & 0.73 & & 172 & 10.69 & 5.70 \\
\hline 4 & $\begin{array}{l}\text { Interaksi sains } \\
\text { dan teknologi } \\
\text { dengan } \\
\text { masyarakat }\end{array}$ & & 2 & 0.73 & & 23 & 1.43 & 1.08 \\
\hline Jum & & & 271 & 100 & & 1609 & 100 & 100 \\
\hline
\end{tabular}

Arief (2015) yang melakukan penelitian terkait literasi saintifik dengan tujuan untuk menggambarkan peningkatan literasi saintifik siswa SMP menggunakan pendekatan levels of inquiry (LOI) dan keterlaksanaan LOI pada kegiatan pembelajaran. Peningkatan yang dilihat ialah domain kompetensi dan pengetahuan pada pembelajaran ilmu pengetahuan alam (IPA) tema pemanasan global. Berikut ialah tahapan kegiatan pembelajaran pada pendekatan LOI: 
Tabel 2.2. Tahapan Pembelajaran pada LOI

\begin{tabular}{|c|c|}
\hline Tahapan & Tujuan Primer Pedagogik \\
\hline Discovery learning & $\begin{array}{l}\text { Siswa memgembangkan konsep } \\
\text { dasar dari pengalaman langsung } \\
\text { (fokus pada keterlibatan untuk } \\
\text { membangun pengetahuan) }\end{array}$ \\
\hline Interative Demonstration & $\begin{array}{l}\text { Siswa dilibatkan dalam } \\
\text { penjelasan dan perumusan } \\
\text { prediksi dengan dibimbing guru } \\
\text { untuk memperoleh, } \\
\text { mengidentifikasi, menghadapi, } \\
\text { memecahkan konsepsi alternatif } \\
\text { (pengalaman } \\
\text { sebelumnya) }\end{array}$ \\
\hline Inquiry lab & $\begin{array}{l}\text { Siswa menentukan hukum } \\
\text { empiris berdasarkan pengukuran } \\
\text { dari variabel (kerja kolaboratif } \\
\text { digunakan untuk membangun } \\
\text { pengetahuan yang lebih rinci) }\end{array}$ \\
\hline Real-world applications & $\begin{array}{l}\text { Siswa menyelesaikan masalah } \\
\text { yang dihubungkan ke situasi } \\
\text { nyata secara individu atau } \\
\text { kerjasama dan kolaborasi } \\
\text { kelompok menggunakan } \\
\text { masalah dasar dan pendekatan } \\
\text { berbasis percobaan }\end{array}$ \\
\hline Hypothetical inquiry & $\begin{array}{l}\text { Siswa menghasilkan penjelasan } \\
\text { untuk fenomena yang diamati } \\
\text { (percobaan lebih realistis dari } \\
\text { pengetahuan siswa) }\end{array}$ \\
\hline
\end{tabular}


Penelitian tersebut menggunakan metode eksperimen lemah dengan desain penelitian one group pretest-postest dan teknik pengambilan sampel nonrandom sampling sebanyak 35 siswa. Analisis data yang dilakukan dengan menggunakan uji wilcoxon menunjukkan bahwa nilai posttest (mean 13,23; SD 4,04) literasi saintifik siswa lebih baik ( $p$-value kurang dari 0.001) dibandingkan nilai pretest literasi saintifik (mean 7,94; SD 3,04). Temuan dalam penelitian ini ialah kompetensi menjelaskan fenomena ilmiah dan kompetensi menafsirkan data dan bukti ilmiah meningkat secara signifikan, sedangkan kompetensi mengevaluasi dan merancang penyelidikan ilmiah tidak meningkat secara signifikan serta pengetahuan konten, prosedural, dan epistemik meningkat secara signifikan. Oleh karena itu dapat disebut bahwa penerapan LOI pada pembelajaran IPA tema pemanasan global dapat meningkatkan domain kompetensi dan pengetahuan literasi saintifik siswa SMP.

Serupa dengan Arief (2015), Utari, dkk. (2015) juga melakukan penelitian terkait literasi saintifik dengan tujuan untuk memberikan saran terhadap desain pembelajaran sains yang diharapkan bisa melatihkan literasi saintifik. Penelitian ini memberikan luaran berupa hasil analisis konten kurikulum dan rancangan rencana pelaksanaan pembelajaran (RPP) yang disusun oleh guru yang bersangkutan. Penelitian tersebut menunjukkan bahwa memang masih terdapat banyak kekurangan yang terdapat pada RPP yang disusun oleh guru dalam melatihkan literasi saintifik. Kekurangan tersebut antara lain pada langkah observasi siswa tidak diarahkan untuk menggunakan pengetahuan ilmiah serta siswa belum ditunjukkan pentingnya materi yang dipelajari dan konteks personal maupun global yang terkait pada langkah pendahuluan. Berdasarkan analisis yang dilakukan, disusun desain pembelajaran yang dapat diterapkan pada kegiatan pembelajaran untuk melatikan literasi saintifik pada siswa serta mengobservasi sikap dari siswa yang memiliki literasi saintifik pada setiap kategori.

Berdasarkan pemaparan beberapa penelitian tersebut, penelitian ini merupakan penelitian lanjutan. Peneliti memandang bahwa desain 
pembelajaran luaran Utari, dkk. (2015) dapat diterapkan untuk mendapatkan hasil analisis berupa tanggapan siswa selama pembelajaran dan peningkatan literasi saintifik siswa. Sementara luaran dari Udompong dan Wongwanich (2014), Kurnia (2014), dan Arief (2015) menjadi bahan pertimbangan dalam perekonstruksian desain pembelajaran. 


\section{BAB III}

\section{METODE PENELITIAN}

\section{A. Desain penelitian}

Penelitian yang dilakukan bertujuan untuk mendapat gambaran tanggapan siswa selama pembelajaran dan peningkatan kemampuan literasi saintifik siswa setelah diterapkan pendekatan saintifik pada topik gerak lurus di Sekolah Menengah Pertama (SMP). Luaran yang diharapkan dari hasil penelitian ini berupa hasil analisis desain pembelajaran dengan menggunakan pendekatan saintifik untuk melatihkan literasi saintifik pada topik gerak lurus. Oleh karena itu, diperlukan data literasi saintifik siswa sebelum dan setelah melakukan kegiatan pembelajaran.

Berdasarkan tujuan penelitian dan kebutuhan data, metode penelitian yang dipilih pre-experimental dengan desain one-group pretestposttest design (Creswell, 2014, hlm. 219-220). Pada metode ini, tidak diperlukan kelompok kontrol untuk dibandingkan dengan kelompok eksperimen, tidak menggunakan penyamaan karakteristik dalam satu kelompok perlakuan, dan tidak memerlukan pengontrol variabel (Creswell, 2014, hlm. 219). Desain penelitian yang digunakan berupa dua kali observasi, yakni sebelum $\left(\mathrm{O}_{1}\right)$ dan setelah $\left(\mathrm{O}_{2}\right)$ diberikan perlakuan $(\mathrm{X})$, ditunjukkan dengan tabel berikut:

Tabel 3.1. Penelitian One-Group Pretest-Posttest Design

\begin{tabular}{lll}
\hline $\mathbf{O}_{\mathbf{1}}$ & $\mathbf{X}$ & $\mathbf{O}_{\mathbf{2}}$ \\
\hline pretest & penerapan pendekatan saintifik & Posttest \\
\hline Dengan: & \\
$\mathrm{O}_{1} \quad=$ Observasi sebelum diberikan perlakuan \\
$\mathrm{O}_{2} \quad=$ Observasi setelah diberikan perlakuan \\
$\mathrm{X} \quad=$ Perlakuan terhadap kelompok eksperimen
\end{tabular}

(Creswell, 2014, hlm. 220) 
Data yang diperoleh berupa skor pretest dan posttest diolah menggunakan gain yang dinormalisasi $\langle g\rangle$ untuk menggambarkan nilai peningkatan posttest terhadap pretest (Hake, 1998, hlm. 65).

\section{B. Populasi dan Sampel}

Subjek penelitian ini ini merupakan siswa dengan rentang usia 1315 tahun. Populasi dalam penelitian ini adalah siswa kelas VII di salah satu SMP Negeri di Kabupaten Bandung Barat yang berada di bawah pengajaran guru yang sama sebanyak 144 siswa. Semua siswa berada pada rentang usia 13-14 tahun. Pengambilan sampel dari populasi ini menggunakan teknik convenience sampling (Creswell, 2014, hlm. 204). Teknik ini dipilih karena peneliti tidak dapat mengubah susunan kelas yang sudah dibentuk sebelum dilakukan penelitian. Sampel dalam penelitian ini sebanyak 25\% dari populasi atau sama dengan 36 sampel, yang sudah memenuhi syarat pengambilan sampel dalam metode penelitian eksperimen menurut Fraenkel \& Wallen (2009, hlm. 102).

\section{Instrumen Penelitian}

Instrumen penelitian yang digunakan mempengaruhi kualitas data yang didapatkan. Adapun instrumen yang digunakan untuk mendapatkan data yang diperlukan dalam penelitian ini adalah instrumen tes tipe uraian Soal Literasi Saintifik (SLS) dan Lembar Kegiatan Siswa (LKS) yang didukung dengan video pembelajaran. Dalam penelitian ini, instrumen SLS yang digunakan adalah hasil adopsi dari Setiawan (2016). Adopsi dilakukan karena peneliti memandang luaran Setiawan (2016) selaras dengan tujuan penelitian, dengan keabsahan (validity) sudah layak, dan nilai koefisien keandalan (reliability) sebesar 0,72. Sementara LKS yang digunakan adalah hasil adaptasi dari Alam (2015). Adaptasi dilakukan untuk menyelaraskan LKS yang telah disusun dengan konteks ketika penelitian ini dilakukan.

\section{Prosedur Penelitian}

Prosedur penelitian meliputi:

\section{Tahap Persiapan}

a. Kajian pustaka, meliputi kajian teoretis dan penelitian terkait; 
b. Menganalisis instrumen;

c. Menentukan sekolah tempat penelitian; serta

d. Mengurus administrasi terkait pelaksanaan penelitian.

\section{Tahap Pelaksanaan}

a. Memilih sampel dari populasi yang diteliti;

b. Mengonfirmasi keselarasan sampel yang dipilih dengan metode yang digunakan;

c. Memutuskan sampel yang digunakan;

d. Mengujikan soal literasi saintifik sebelum diberikan perlakuan (pretest);

e. Memberikan perlakuan berupa penerapan kegiatan pembelajaran dengan pendekatan saintifik untuk melatihkan literasi saintifik siswa. Selama perlakuan diberikan, dilakukan perekaman kegiatan; serta

f. Mengujikan soal literasi saintifik setelah diberikan perlakuan (posttest)

\section{Tahap Penyelesaian}

a. Melakukan analisis tanggapan siswa selama pembelajaran;

b. Mengoreksi jawaban siswa pada LKS dan SLS;

c. Mengolah jawaban siswa pada SLS untuk melihat peningkatan literasi saintifik; dan

d. Menyelaraskan seluruh naskah penelitian.

Prosedur penelitian dapat dilihat pada Gambar 3.1. 
Gambar 3.1. Prosedur Penelitian

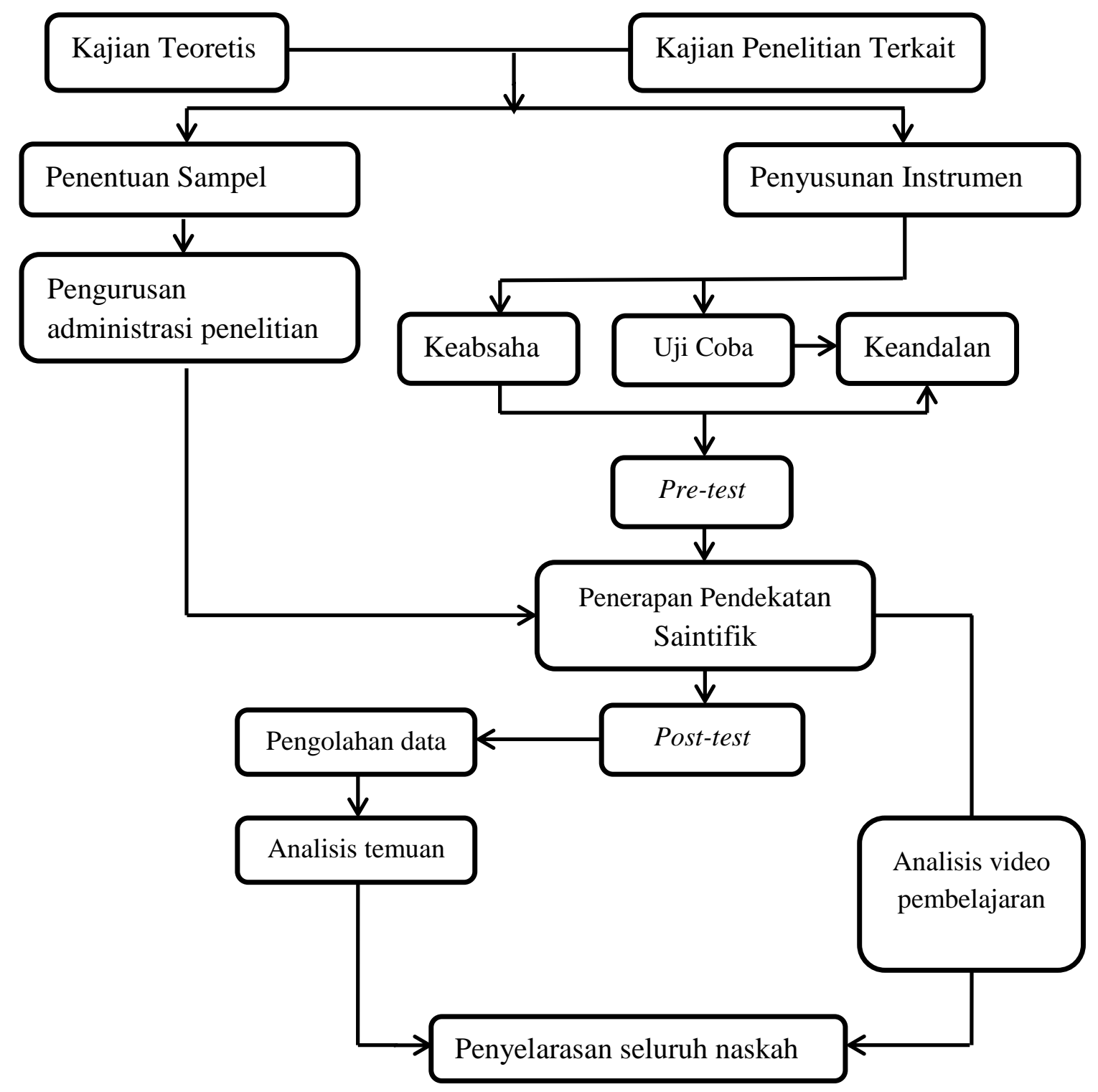

\section{E. Teknik Analisis Data}

Analisis data dilakukan pada setiap data yang diperoleh dalam penelitian ini. Adapun analisis pada masing-masing data sebagai berikut :

\section{Soal Literasi Saintifik}

Dengan menggunakan soal berbentuk essay sebanyak 18 butir soal, penyekoran pre-test dan post-test setiap siswa yang menjadi sampel penelitian dilakukan dengan menggunakan persamaan berikut: 
$S=\sum R$ (Persamaan 3.1. Penyekoran Pre-Test dan Post-Test)

Dengan:

$\mathrm{S} \quad=$ skor siswa

$\mathrm{R} \quad=$ jawaban tepat

Dari skor pretest dan posttest, nilai gain yang dinormalisasi $\langle g\rangle$ dihitung dengan menggunakan persamaan berikut:

$<g>=\frac{\% \text { skor posttest } \% \text { skor pretest }}{100-\% \text { skor pretest }}$ (Persamaan 3.2. Nilai Gain)

(Diadaptasi dari Hake, 1998, hlm. 65)

Hasil perhitungan ditafsirkan berdasarkan tabel berikut:

Tabel 3.2. Kategori Peningkatan Nilai Gain

\begin{tabular}{cl}
\hline \multicolumn{1}{c}{$<g>$} & Kategori \\
\hline $0,00<g \leq 0,30$ & Rendah \\
\hline $0,30<g \leq 0,70$ & Sedang \\
\hline $0,70<g \leq 1,00$ & Tinggi
\end{tabular}

(Hake, 1998, hlm. 65)

\section{Lembar Kegiatan Siswa (LKS)}

Langkah yang dilakukan oleh peneliti untuk mendapatkan data dari LKS ialah sebagai berikut:

a. Menyusun rubrik jawaban LKS;

b. Menganalisis jawaban LKS setiap siswa;

c. Melakukan perhitungan persentase siswa yang menjawab pertanyaan secara tepat dalam LKS; serta

d. Menganalisis video pembelajaran pada setiap tahapan yang terdapat dalam pendekatan saintifik. 


\section{BAB IV}

\section{TEMUAN DAN PEMBAHASAN}

Penelitian yang telah dilakukan di salah satu SMP Negeri di Kabupaten Bandung Barat bertujuan untuk melihat peningkatan literasi saintifik siswa dalam domain kompetensi pada topik gerak lurus. Cara yang dilakukan oleh peneliti untuk meningkatkan literasi saintifik siswa ialah memberikan perlakuan pada kelas eksperiman berupa pembelajaran menggunakan pendekatan saintifik selama tiga pertemuan berturut-turut. Ketika perlakuan diberikan, siswa diminta untuk memberikan tanggapan melalui Lembar Kegiatan Siswa (LKS) yang disusun secara urut seperti tahapan pendekatan saintifik. Berdasarkan penelitian yang dilakukan, didapatkan informasi mengenai tanggapan siswa selama pembelajaran sebagai berikut:

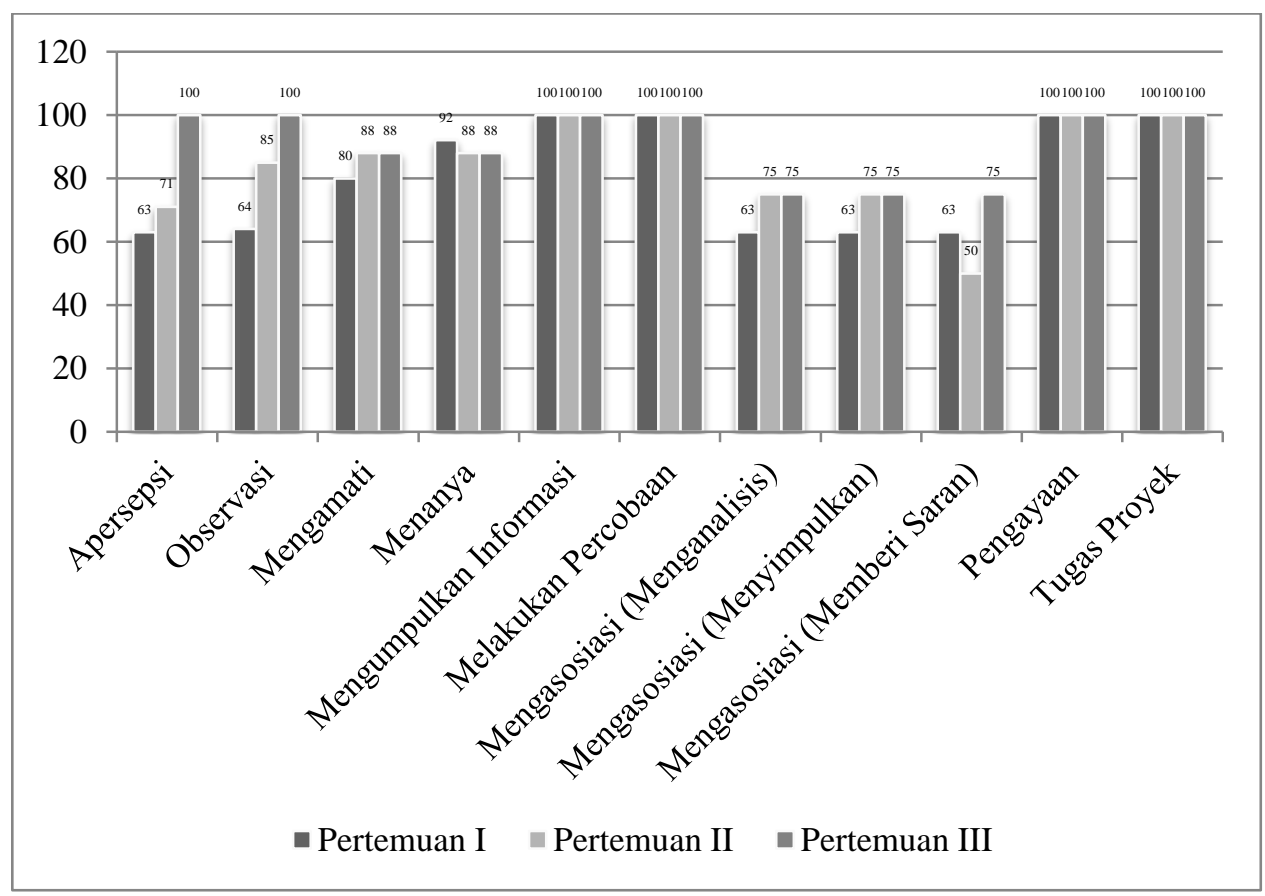

Gambar 4.1. Tanggapan Siswa Selama Pembelajaran

Dari Gambar 4.1. tersebut terlihat bahwa tanggapan siswa selama pembelajaran bisa maksimal untuk seluruh pertemuan pada tahap Mengumpulkan Informasi, Melakukan Percobaan, Pengayaan, dan Tugas Proyek. Pada tahap Mengumpulkan Informasi dan Melakukan Percobaan, siswa 
tidak diminta untuk memberikan tanggapan secara tertulis melainkan tanggapan berupa keikutsertaan siswa bersama kelompoknya. Sedangkan pada tahap

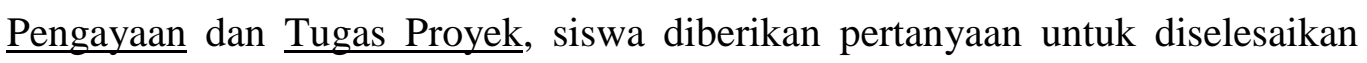
secara berkelompok (jawaban dari setiap kelompok). Pada langkah Menanya, terjadi penuruan keikutsertaan siswa dari pertemuan pertama ke pertemuan kedua dan ketiga karena tanggapan yang diberikan siswa berupa pertanyaan penyelidikan kurang tepat. Penurunan juga terjadi pada tahap Memberikan $\underline{\text { Saran, }}$ yaitu dari pertemuan pertama ke pertemuan kedua, namun mengalami peningkatan dari pertemuan kedua ke pertemuan ketiga. Temuan ini karena pada pertemuan kedua, siswa banyak yang tidak memberikan tanggapan secara tertulis.

Berikut adalah hasil keseluruhan peningkatan literasi saintifik siswa yang didapatkan dengan menggunakan nilai gain yang dinormalisasi $\langle g\rangle$.

Tabel 4.1. Peningkatan Literasi Saintifik

\begin{tabular}{lll}
\hline Rata-rata pre-test & Rata-rata post-test & N-Gain \\
\hline 4,61 & 15,52 & 0,61
\end{tabular}

Berdasarkan Tabel 3.2. maka peningkatan literasi saintifik siswa dalam domain kompetensi pada topik gerak lurus secara keseluruhan ialah pada kategori sedang. Peningkatan dengan nilai gain yang dinormalisasi sebesar 0,61 menunjukkan bahwa lebih dari setengah dari seluruh jumlah siswa dalam penelitian ini memenuhi indikator domain kompetensi literasi saintifik.

Domain kompetensi dikelompokkan ke dalam tiga kompetensi, yaitu Menjelaskan Fenomena Ilmiah (K1), Merancang dan Mengevaluasi

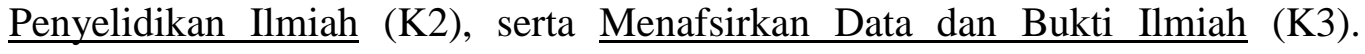
Peningkatan literasi saintifik pada ketiga domain kompetensi dalam setiap pertemuan dapat dilihat pada Gambar 4.2. yang memperlihatkan bahwa peningkatan paling signifikan terjadi pada Pertemuan I dalam K3. Gambar 4.2. juga menunjukkan kecenderungan peningkatan literasi saintifik untuk setiap pertemuan hanya terjadi pada $\mathrm{K} 2$, sedangkan pada $\mathrm{K} 1$ dan $\mathrm{K} 3$ justru mengalami penurunan dan perubahan yang tidak laras untuk setiap pertemuan. 


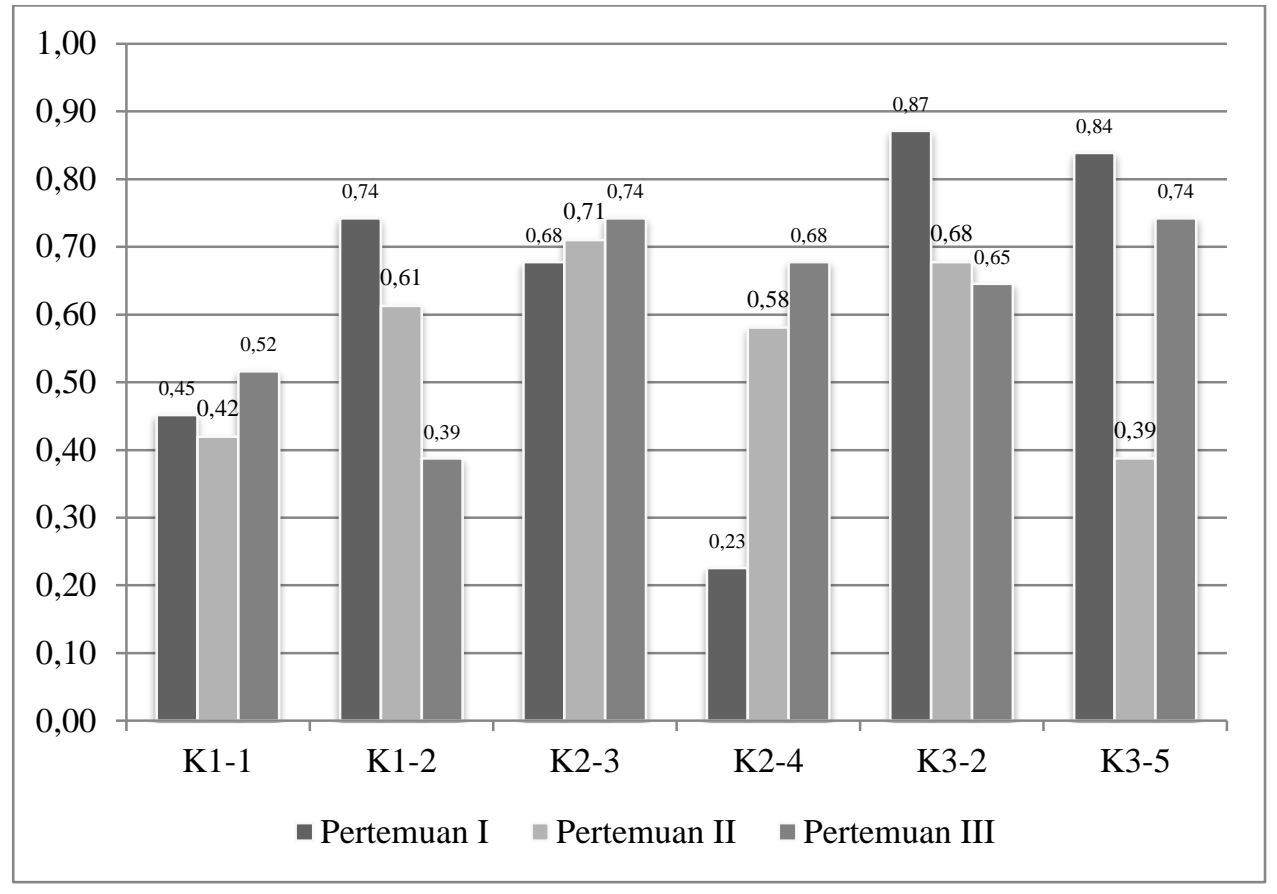

Gambar 4.2. Peningkatan Setiap Domain Dalam Setiap Pertemuan

Peningkatan pada K1 dengan nilai gain yang dinormalisasi sebesar 0,52 menunjukkan bahwa siswa yang mampu menjelaskan fenomena secara ilmiah baru sekitar setengah dari seluruh jumlah siswa. K1 diukur berdasarkan dua indikator, ialah Mengingat dan Menerapkan Pengetahuan Ilmiah yang Sesuai (K1-1) serta Mengidentifikasi, Menggunakan, dan Menghasilkan Model yang Jelas dan Representatif (K1-2). Untuk setiap pertemuan, kedua indikator ini memberikan hasil yang berbeda. K1-1 mengalami perubahan yang tdiak laras berupa penurunan dari Pertemuan 1 ke Pertemuan 2 serta peningkatan dari Pertemuan 2 ke Pertemuan 3 mengalami peningkatan. K1-2 mengalami perubahan yang laras berupa penurunan untuk setiap pertemuan.

Perubahan tidak laras juga terjadi pada domain Menafsirkan Data dan Bukti Ilmiah (K3) dengan nilai gain yang dinormalisasi sebesar 0,69. K3 diukur berdasarkan dua indikator, ialah Mengevaluasi Argumen Ilmiah dan Bukti dari Berbagai Sumber (K3-2) serta Menganalisis dan Menafsirkan Data serta Menarik Kesimpulan yang Tepat (K3-5). K3-2 mengalami perubahan yang laras berupa penurunan untuk setiap pertemuan, bahkan penurunan sangat curam dari Pertemuan 1 ke Pertemuan 2. K3-5 mengalami perubahan yang tidak laras 
penurunan dari Pertemuan 1 ke Pertemuan 2 dan peningkatan dari Pertemuan 2 ke Pertemuan 3. Perbedaan yang sangat besar antara Pertemuan 2 dengan dua pertemuan lainnya pada K3-5 membuat penurunan dan peningkatan yang terjadi terlihat paling jelas.

Dari ketiga domain, hanya peningkatan pada K2 dengan nilai gain yang dinormalisasi sebesar 0,60 yang menunjukkan perubahan yang laras. K2 diukur berdasarkan dua indikator, berupa Mengusulkan Cara Mengeksplorasi Pertanyaan yang Diberikan Secara Ilmiah (K2-3) serta Mengevaluasi Cara Mengeksplorasi Pertanyaan yang Diberikan Secara Ilmiah (K2-4), mengalami peningkatan untuk setiap pertemuan. Namun peningkatan untuk Pertemuan 1 ke Pertemuan 2 pada K2-4 terlihat paling tajam.

Secara keseluruhan, peningkatan literasi saintifik siswa tidak terjadi secara konsisten dari domain ke domain serta dari pertemuan ke pertemuan yang ditunjukkan dengan simpangan nilai rata-rata yang cukup besar. Ketidakkonsistenan ini menyulitkan peneliti dalam menyimpulkan gambaran umum peningkatan literasi saintifik siswa berkaitan dengan pertemuan. Kesulitan ini terjadi karena pada indikator dan pertemuan tertentu peningkatan sangat tajam dan penurunan sangat curam dibanding nilai rata-rata peningkatan keseluruhan.

Berdasarkan pemaparan temuan tanggapan siswa selama pembelajaran dan peningkatan literasi saintifik siswa, tampak kecenderungan data ialah semakin maksimal tanggapan diberikan, semakin optimal peningkatan literasi saintifik yang didapatkan. Namun kecenderungan ini tidak berlaku pada tahap Tugas Proyek untuk Pertemuan I.

Ketidakberlakuan kecenderungan didapatkan karena sebagian besar siswa tidak tepat dalam menjawab SLS. Pada SLS ditanyakan tentang pengukuran perpindahan menggunakan Odometer dengan jawaban yang diharapkan ialah siswa menjawab bahwa cara tersebut tidak tepat karena Odometer mengukur jarak bukan perpindahan. Namun sebagian besar siswa menjawab bahwa cara tersebut sudah tepat. 
Indikator pada Tugas Proyek menuntut siswa untuk bisa Mengevaluasi Cara Mengeksplorasi Pertanyaan yang Diberikan Secara Ilmiah. Evaluasi yang ditekankan berupa kecermatan siswa dalam menemukan kesalahan cara mengeksplorasi berdasarkan pengetahuan yang telah mereka miliki. Dari ketiga pertemuan, hanya pada Pertemuan 1 peningkatan yang dialami memberikan nilai paling kecil dengan nilai gain yang dinormalisasi sebesar 0,23 sedangkan pada Pertemuan 2 dan 3 masing-masing sebesar 0,58 dan 0,68.

Konsep dasar yang diangkat pada bagian ini berupa perbedaan Jarak dan Perpindahan seperti pada indikator K1-1 dan K1-2 untuk Pertemuan I. Kedua indikator tersebut memberikan nilai gain yang dinormalisasi masing-masing sebesar 0,45 dan 0,74. Hasil ini menunjukkan bahwa siswa sudah bisa memahami perbedaan konsep jarak dan perpindahan namun belum bisa menerapkan untuk mengevaluasi cara mengeksplorasi pertanyaan yang memerlukan pemahaman terhadap perbedaan kedua konsep tersebut.

Karena dibandingkan terhadap indikator dengan konsep yang sama serta tahapan yang sama simpangan nilainya sangat besar, peneliti kesulitan untuk menyebut bahwa siswa belum bisa mencapai indikator ini pada pertemuan ini tanpa disertai penjelasan lebih lanjut. Peneliti hanya bisa menjelaskan bahwa siswa sudah bisa memahami konsep Jarak dan Perpindahan namun belum bisa menguasasi untuk diterapkan pada kasus tertentu yang memerlukan pemahaman terhadap kedua konsep tersebut. 


\section{BAB V}

\section{SIMPULAN, IMPLIKASI, DAN REKOMENDASI}

\section{A. Simpulan}

Berdasarkan temuan dan pembahasan hasil penerapan pendekatan saintifik untuk melatihkan literasi saintifik dalam domain kompetensi pada topik gerak lurus di sekolah menengah pertama (SMP), dapat disimpulkan sebagai berikut:

1. Desain pembelajaran dengan menggunakan pendekatan saintifik yang telah dirancang mendapat tanggapan siswa hampir maksimal pada setiap tahap kegiatan pembelajaran.

2. Secara keseluruhan literasi saintifik siswa mengalami peningkatan pada kategori sedang setelah diterapkan pendekatan saintifik yang menunjukkan bahwa kegiatan pembelajaran bisa melatihkan literasi sainifik namun belum bisa optimal.

\section{B. Implikasi}

Secara teoretis penelitian ini berhubungan dengan peran penelitian ini bagi pengembangan kajian pendidikan fisika dan IPA untuk sekolah menengah. Sementara secara praktis penelitian ini ikut serta memberikan penguatan pelaksanaan pembelajaran fisika dan IPA yang bisa melatihkan literasi saintifik pada siswa untuk untuk sekolah menengah.

Meskipun demikian, peneliti memberikan saran terkait penelitian ini yang diharapkan dapat dijadikan sebagai bahan pertimbangan untuk perbaikan dan/atau kelanjutan penelitian ini. Sehingga penelitian yang dilakukan bisa semakin memberikan sumbangan terhadap kajian maupun pelaksanaan pendidikan, terutama pada topik pendidikan fisika dan IPA di Indonesia.

Beberapa kegiatan yang dapat dilakukan untuk menindaklanjuti hasil penelitian ini antara lain:

1. Pada penelitian ini, peningkatan literasi saintifik siswa masih belum terungkap secara menyeluruh berdasarkan indikator pada kerangka kerja PISA 2015. Oleh karena itu, perlu dilakukan pengembangan 
instrumen yang mampu mengukur seluruh indikator tersebut sehingga instrumen tersebut mampu menggambarkan peningkatan literasi saintifik siswa dengan tepat.

2. Topik yang diajarkan pada penelitian ini juga baru pada topik gerak lurus, sehingga perlu dilakukan penerapan pada topik lainnya agar mampu meningkatkan literasi saintifik siswa pada seluruh topik pembelajaran. Dengan demikian, literasi saintifik siswa bisa semakin optimal.

3. Penerapan pendekatan saintifik yang dilakukan pada penelitian ini belum meningkatkan literasi saintifik siswa secara optimal. Oleh karena itu, perlu dilakukan perbaikan berkelanjutan pada pelaksanaan maupun desain pembelajaran. Supaya perbaikan lebih optimal, peneliti menyarankan agar ujicoba dilakukan ke tiga sekolah setara dengan tingkat yang berbeda (tinggi, sedang, dan rendah).

4. Untuk menegaskan bahwa pendekatan saintifik memang bisa meningkatkan literasi saintifik siswa, penelitian selanjutnya menggunakan kelas pembanding yang menerapkan desain pembelajaran tidak sama.

5. Sebelum desain pembelajaran ini diterapkan, peneliti mengharapkan agar pengetahuan matematika yang diperlukan pada kegiatan pembelajaran sudah dikuasi atau minimal telah dipahami dengan tepat oleh siswa.

\section{Rekomendasi}

Penerapan desain pembelajaran dengan menggunakan pendekatan saintifik secara malar pada kegiatan pembelajaran topik gerak lurus dapat meningkatkan literasi saintifik siswa. Pendekatan saintifik merupakan salah satu pendekatan pembelajaran yang dilakukan secara bertahap mulai dari langkah yang melatih kemampuan dasar siswa hingga kemampuan kompleks. Sementara literasi saintifik dipandang penting untuk dimiliki, sehingga para pelaku pendidikan fisika dan IPA dituntut agar bisa merancang desain pembelajaran yang bisa melatihkan literasi saintifik siswa. Pendekatan saintifik dipandang cocok digunakan untuk melatihkan 
literasi saintifik siswa sekolah menengah pertama (SMP) karena siswa tidak hanya diberi informasi melainkan dipancing agar ikut serta mencari informasi dengan bekal pengetahuan yang telah dimiliki. Topik gerak lurus dipilih dalam penelitian ini dengan alasan bahwa banyak topik lain di fisika bergantung pada topik ini. Dengan demikian, desain pembelajaran yang dirancang pada penelitian ini dengan pendekatan saintifik untuk melatihkan literasi saintifik pada topik gerak lurus dapat ikut serta memperkaya kajian keilmuan pendidikan fisika dan IPA. 


\section{DAFTAR PUSTAKA}

Alam, D.P. (2015). Rekonstruksi rancangan rencana pelaksanaan pembelajaran sains melalui analisis kesulitan literasi sains siswa smp kelas vii padatopik gerak lurus. Dalam Irwanto, D., Akbar. F.Taufik., dan Aimon, A.H. (Penyunting), Prosiding Simposium Nasional Inovasi dan Pembelajaran Sains 2015 (SNIPS 2015). Bandung: Institut Teknologi Bandung.

Arief, M. K. (2015). Implementation of levels of inquiry on science learning to improve junior high school student's scientific literacy. Jurnal Pendidikan Fisika Indonesia 11 (2), hlm. 117-125.

Creswell, J.W. (2014). Research design : qualitative, quantitative, and mixed methods approaches (4th ed.). Thousand Oaks: SAGE Publications, Inc.

Cronbach, L. J. (1951). Coefficient alpha and the internal structure of tests. Psychometrika, 16, hlm. 297-334.

Fraenkel, J.R. \& Wallen, N.E. (2009). How to design and evaluate research in education (7th ed.). New York. McGraw-Hill Companies.

Hake, R.R. (1998). Interactive-engagement versus traditional methods: a six-thousand-student survey of mechanics test data for introductory physics courses. American Journal of Physics 66, (1), hlm. 64-74.

Holbrook, J. \& Rannikmae, M. (2009). The meaning of scientific literacy. International Journal of Environmental \& Science Education, 4 (3), hlm. 275-288.

Hurd, P.deH. (1958). Science literacy: its meaning for american schools. Educational Leadership, 16, hlm. 13-16.

Kementerian Pendidikan dan Kebudayaan. (2013). Peraturan menteri pendidikan dan kebudayaan republik indonesia nomor 81a tahun 2013 tentang implementasi kurikulum. Jakarta: Kementerian Pendidikan dan Kebudayaan.

Kurnia, F. (2014). Analisis bahan ajar fisika sma kelas XI di kecamatan indralaya utara berdasarkan kategori literasi sains. Jurnal Inovasi dan Pembelajaran Fisika, 1 (1), hlm. 43-47.

NAS. (1996). National science education standards. Washington, D.C.: National Academy Press. 
Novili, W.I. (2016). Penerapan scientific approach untuk meningkatkan literasi saintifik dalam domain kompetensi siswa smp pada topik kalor. Jurnal Penelitian \& Pengembangan Pendidikan Fisika, 2 (1), hlm. 51-56.

OECD. (2013). PISA 2015 draft science frame work. Paris: OECD.

OECD. (2016). PISA 2015 Results in Focus. Paris: OECD.

Sari, A.P.P. (2016). Pengembangan lembar kegiatan peserta didik (lkpd) berbasis scientific approach siswa sma kelas x pada materi fungi. Jurnal Pendidikan Biologi Universitas Muhammadiyah Metro, 7 (1), hlm. 41-48.

Setiawan, A.R. (2016). Mengonstruksi rancangan soal domain kompetensi literasi saintifik siswa smp kelas viii pada topik gerak lurus. Dalam Seminar Nasional Fisika (SiNaFi). Bandung: Universitas Pendidikan Indonesia.

Sudarisman, S. (2011). Tugas rumah berbasis home science process skill (hsps) pada pembelajaran biologi untuk mengembangkan literasi sains siswa. Dalam Prosiding Seminar Nasional VIII Pendidikan Biologi (hlm. 253-260). Surakarta: Universitas Sebelas Maret.

Udompong, T. \& Wongwanich, S. (2014). Diagnosis of the scientific literacy characteristics of primary students. Procedia - Social and Behavioral Sciences, 116, hlm. 5091-5097.

Utari, S. dkk. (2015). Designing science learning for training students' science literacies at junior high school level. Dalam International Conference on Mathematics, Science, and Education. Semarang: Universitas Negeri Semarang. 